\title{
Spectroscopic and Thermal Degradation Study of Cow-Dung during Combustion and Pyrolysis
}

\author{
Abdul Munam ${ }^{\text {a }}$, Jahangir Ahmad Rather ${ }^{\text {a }}$, Tansir Ahamad \\ ${ }^{a}$ Department of Chemistry, Sultan Qaboos University, Box 36, Al-Khod 123, Oman \\ ${ }^{\mathrm{b}}$ Department of Chemistry, King Saud University, Riyadh, Kingdom of Saudi Arabia \\ "Munama@squ.edu.om
}

\begin{abstract}
This study reports the analysis of gases evolved during controlled pyrolysis and combustion of cowdung. The combined thermogravimetric (TG)/ Fourtier transform infrared (FTIR)/ mass spectrometry (MS) were employed to analyze the evolved gaseous products. The results revealed that the thermal decomposition of cow-dung occurs in three steps assigned to drying of the sample, fast thermal decomposition and further cracking. The complete combustion of cow-dung occurs at $500^{\circ} \mathrm{C}$, while during pyrolysis the total weight loss of $58.91 \mathrm{wt} . \%$ was found at $950^{\circ} \mathrm{C}$. The release of gaseous product during pyrolysis was $\mathrm{CO}_{2}, \mathrm{CO}$, methanol, formaldehyde, formic acid, acetic acid, whereas the products during combustion were $\mathrm{CO}_{2}, \mathrm{CO}$. Among them, $\mathrm{CO}_{2}$ was the dominant gaseous product in the whole combustion process.
\end{abstract}

Keywords: Cow-dung; Thermal degradation; Hazardous materials; TG-FTIR-MS.

\section{INTRODUCTION}

More than half of the global population lacking clean cooking facilities lives in India, China and Bangladesh," says the UN report. According to WHO countries like India, Nepal, Pakistan and Sri Lanka used biomass as fuel for daily household cooking. Nearly 3 billion people depend on solid fuels (biomass and coal) for cooking and heating and this number is expected to grow until at least $2030[1,2]$. Incomplete combustion of biomass is the main source of indoor air pollution worldwide [3] and in most developing countries; it is burned in open that produces a lot of smoke. The biomass produced from the undigested residue of plant matter, which has passed through the animal's gut of bovine animal species such as buffalo, cows, camels, is referred as "Animal Dung" and when this is produced from cow it is named as "Cow-dung", a faecal matter rich in minerals, comprised of organic matter including fibrous material. Exact chemical composition of cow-dung is mostly carbon, hydrogen, oxygen, nitrogen, phosphorus and urea, mucus as well as cellulose, lignin and hemicellulose. Color ranges from greenish to blackish, often darkening in color soon after exposure to air. Cow-dung generally combined with soiled bedding and urine is often used as manure (agricultural fertilizer). In many parts of the developing world, people use caked and dried cow dung as a fuel for their major source of domestic energy [4, 5]. The burning of this material in open fires and stoves for domestic cooking results in high concentrations of particulate matter, carbon monoxide, nitrogen dioxide, as well as volatile and semi-volatile organic species in the indoor environment and is important causes of indoor air pollution [6-8]. This is linked to a number of respiratory problems, $[9,10]$ and considered an important factor for the development of tuberculosis in the rural women of the developing world [11-16].

The combustion of cow-dung produces higher concentration of the carcinogenic polycyclic aromatic hydrocarbon (PAHs) in the breathing zone at the cooking site than that with liquid petroleum gas (LPG) and firewood [17]. It was reported that the continued use of bio-energy in cooking exposes the rural women to greater levels of DNA damage [18]. On the other hand, it is negligent to allow the animal manure to decompose naturally; as such, decomposition emits two highly potent greenhouse gases (GHGs) - nitrous oxide and methane [19, 20]. However, no detailed studies on the real time analysis of gases released during the pyrolysis (under inert) or combustion (under oxidative conditions) of animal dung, more specifically cow-dung is reported. 
In the present study, the gases evolved during pyrolysis and combustion of cow-dung are investigated using TG-FTIR-MS. This is a powerful method for the characterization of the gaseous products, analysis of the decomposition kinetics, investigation of the combustion conditions and the parameters during the combustion of a variety of fuels [21]. Helium is used as the carrier gas during pyrolysis and the weight loss with temperature is recorded automatically. The combustion characteristics at oxygen atmosphere are also studied, because incineration is the most important technology for organic waste disposal. This study is essential for developing comprehensive pyrolysis and combustion models for cow dung and can provide valuable input for their protected disposal and use as a fuel in the rural area of the developing world.

\section{EXPERIMENTS}

\subsection{Materials and Methods}

Cow-dung samples were collected from the rural area of South East Asia and were crushed and pulverized into a size of lower than $0.2 \mathrm{~mm}$ for further analysis. The TG-FTIR-MS experiments were performed using thermogravimetric (STD 600 TA) Instrument coupled with FTIR (Bruker Tensor 27) and mass spectrometer (Thermo). Helium was used as carrier gas with a flow rate of $100 \mathrm{ml} / \mathrm{min}$ during pyrolysis on the other hand oxygen was used as oxidant during combustion at the same flow rate. The coupling system TG-FTIR-MS was heated at $200^{\circ} \mathrm{C}$ to prevent condensation of evolved gases, while the heating rates of the furnace was $10,20,30$ and $50^{\circ} \mathrm{C} / \mathrm{min}$. It was found that the intensity of the thermal decomposition and the emission of gaseous products were slowed down at lower heating rates. Therefore a heating rate of $30^{\circ} \mathrm{C} / \mathrm{min}$ was adopted for thermal decomposition of cow dung. During TGA/FTIR experiments, spectral data are repeatedly collected in the form of interferograms and then processed to build up a Grame Schmidt reconstruction, each point of which corresponds to the total IR absorbance of the evolved components in the range of 4000 to $500 \mathrm{~cm}^{-1}$. The mass spectrometer was operated at $70 \mathrm{eV}$ electron energy. The $\mathrm{m} / \mathrm{z}$ was carried out from 1 to $100 \mathrm{amu}$ to determine which $\mathrm{m} / \mathrm{z}$ has to be followed during the thermal degradation of cow dung. The ion curves close to the noise level were omitted. Finally, only the intensities of 13 selected ions $(\mathrm{m} / \mathrm{z}=12,15,17,18,26,27,28,29,30,34,43,44$, and 45) were monitored with the thermogravimetric parameters.

\section{RESULTS AND DISCUSSION}

Coupling a TG instrument with evolved gas analyzers, such as FTIR and a mass spectrometer, produces a very powerful analytical tool that gives important information regarding the nature and mechanism of thermal decomposition. The TG-FTIR-MS system has suitable interfaces to carry the gaseous decomposition products from the TG furnace to the detection system of FTIR and MS spectrometers, i.e. the method consists of carrying the evolving volatile products out of the furnace directly into the FTIR gas cell and MS where the gases are analyzed.

The TG and derivative thermogravimetric analysis (DTG) data were collected for the thermal degradation of the cow dung during pyrolysis, combustion of $950^{\circ} \mathrm{C}$ pyrolyzed residue, TG and DTG curves at a heating rate of $30^{\circ} \mathrm{C} / \mathrm{min}$ are shown in Figure 1 . The pyrolysis process (Figure 1A) can be divided into three zones: drying zone $\left(<170^{\circ} \mathrm{C}\right)$, main pyrolysis zone $\left(200-500^{\circ} \mathrm{C}\right)$ and cracking zone $\left(>500^{\circ} \mathrm{C}\right)$. The first mass loss $(3.28 \%)$ occurs between 50 and $200^{\circ} \mathrm{C}$ corresponds to the vaporization of moisture and desorption of water. The most significant mass loss (about $45.26 \%$ of the total weight of the sample) appears between 200 and $500^{\circ} \mathrm{C}$ and the maximum weight loss rate $(15.11 \% / \mathrm{min})$ occurred at $348.17^{\circ} \mathrm{C}$. The last zone is the further cracking process of the residues in a wider temperature range, from $500^{\circ} \mathrm{C}$ to $950^{\circ} \mathrm{C}$ and the total weight loss of $58.19 \mathrm{wt} . \%$ was discovered at $950^{\circ} \mathrm{C}$ during pyrolysis with 41.09 wt. $\%$ of non-degraded sample. When it is subjected to complete combustion and about $32.51 \mathrm{wt} \%$ lost occurred between $300^{\circ} \mathrm{C}$ and $550^{\circ} \mathrm{C}$ and no further degradation was observed throughout the experiment temperature rang (Figure 1B).

Comparatively as seen from combustion thermogram (Figure 1C), slightly higher weight loss (8.33\%) occurs in the first zone, 51.22 wt.\% weight lost observed between $200^{\circ} \mathrm{C}$ and $340^{\circ} \mathrm{C}$ and 9.71 wt.\% weight loss between $340^{\circ} \mathrm{C}$ and $500^{\circ} \mathrm{C}$. Therefore the total weight loss of $60.93 \mathrm{wt} . \%$ was seen in the second zone. In this zone, DTG curve (Figure 1C), shows the maximum weight loss rate (134.3\%/min) 
occurred at $312.88^{\circ} \mathrm{C}$. The combustion of the cow-dung finishes after the weight loss peak between $200^{\circ} \mathrm{C}$ and $500^{\circ} \mathrm{C}$. The total weight loss of $72.36 \mathrm{wt} . \%$ was discovered at $950^{\circ} \mathrm{C}$ in cow-dung combustion. There are no other solid products except ash content for cow-dung combustion at high temperature in oxidizing atmosphere. The comprehensive analysis for combustion and pyrolysis shows that almost all the solid products generated from cow dung pyrolysis can be burnt at high temperature, and $500^{\circ} \mathrm{C}$ is enough for complete combustion of this material.
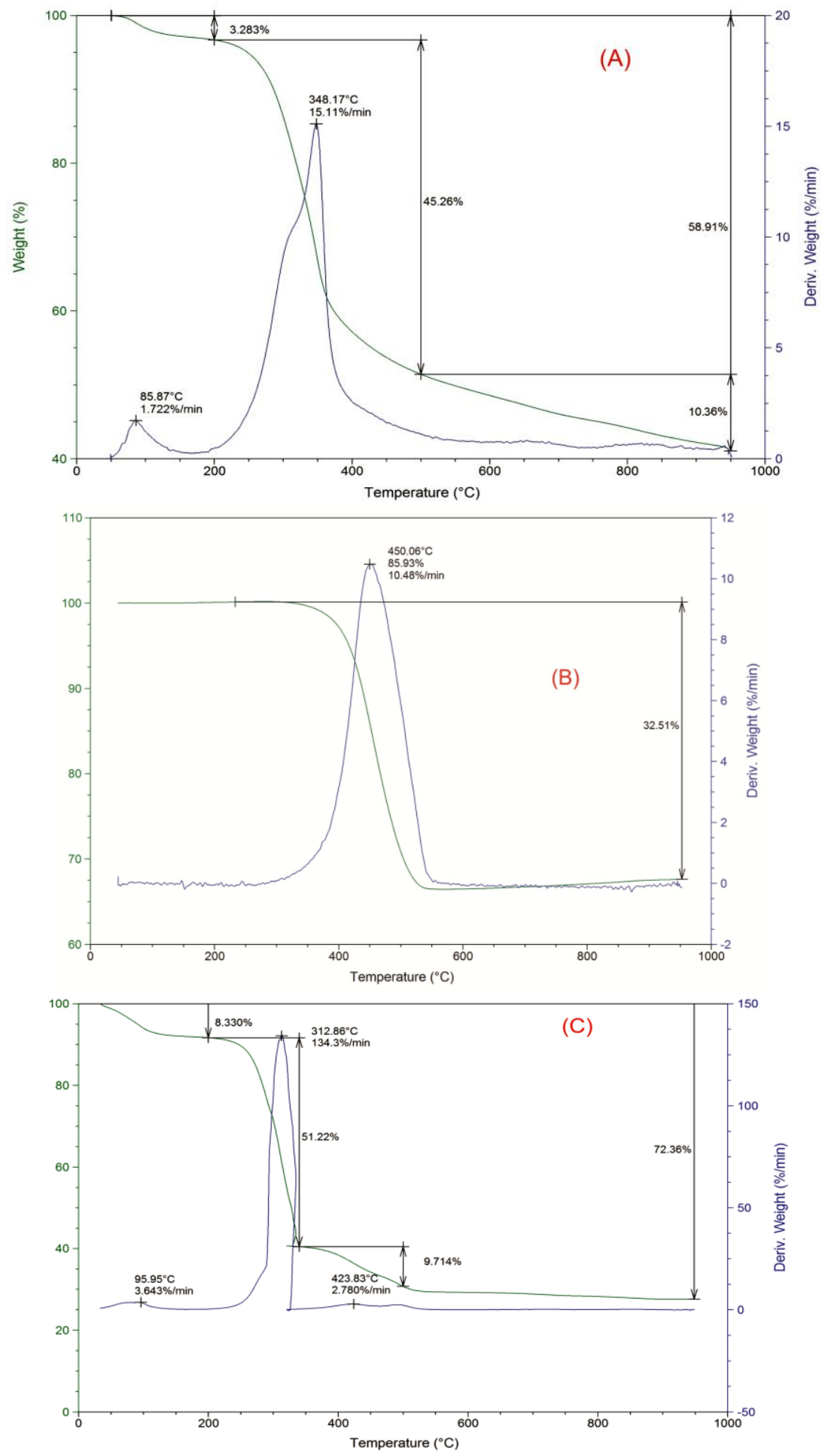

Figure1. TG/DTG Profiles During Thermal Degradation of Cow Dung; (A) Pyrolysis, (B) Combustion Of $950^{\circ} \mathrm{C}$ Pyrolyzed Residue, (C) Combustion. 


\section{Abdul Munam et al.}

Gram-Schmidt reconstructs based on vector analysis of the acquired interferograms allows plots of the total evolved gases detected by the spectrometer to be generated shown in Figure 2. The detector signal has been plotted as a function of sample temperature and qualitatively approximated DTA curves recorded during the TG experiments under different controlled conditions. It should be noted that the peaks in the Gram-Schmidt plot are shifted to higher temperatures than the corresponding DTG curve and this is due to the delay time between the gas generation and its detection in the FTIR equipment. The first peak of small intensity observed in the Gram-Schimid plot during pyrolysis (Figure 2A), suggest that the amount of evolved gas in this stage is low and with low infrared extinction coefficients. Whereas only one peak of high intensity was observed in the Gram Schimid plot during combustion of $960^{\circ} \mathrm{C}$ pyrolyzed residue of cow-dung (Figure 2B), suggested that the amount of the evolved gases in this region is larger and with high infrared extinction coefficients. During the combustion of cow- dung (Figure 2C), three evolved gas regions can be identified and they are related to the mass losses recorded in the DTG curve. First peak is bigger compare to other two peaks of identical intensities, confirms that the amount of the evolved gases in this region is larger with high infrared extinction coefficients. In contrast, the other two peaks are composing of small amount of evolved gases with low infrared extinction coefficients. Figure 3 shows 3D FTIR spectra for the evolved products produced from thermal degradation, whereas the spectrograms at different temperature during pyrolysis and combustion of cow dung are shown in the supplementary material Figures SF1-SF5.
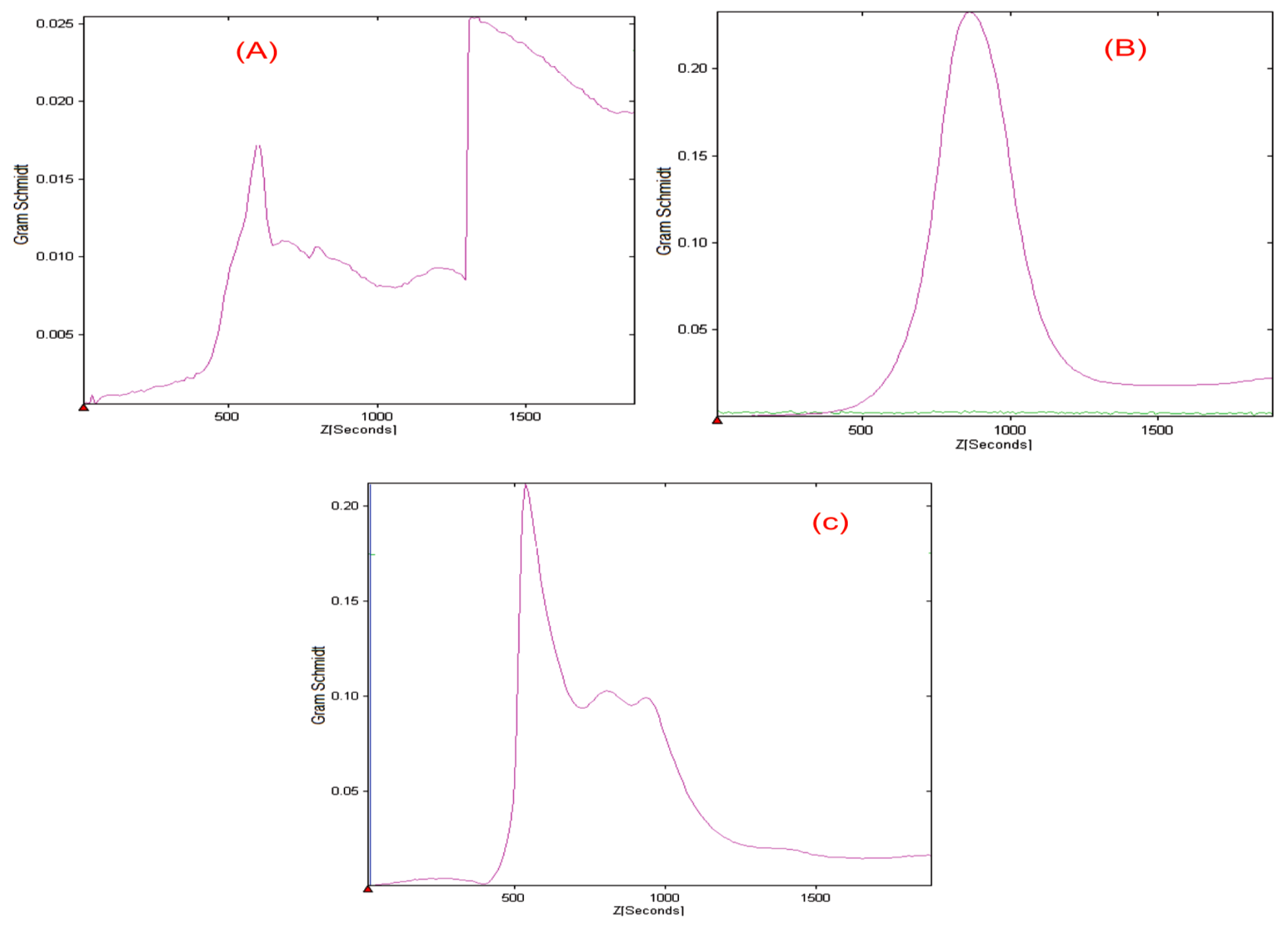

Figure2. Gram-Schmidt Plot of Cow Dung During Thermal Degradation; (A) Pyrolysis, (B) Combustion of $950^{\circ} \mathrm{C}$ Pyrolyzed Residue, (C) Combustion. 

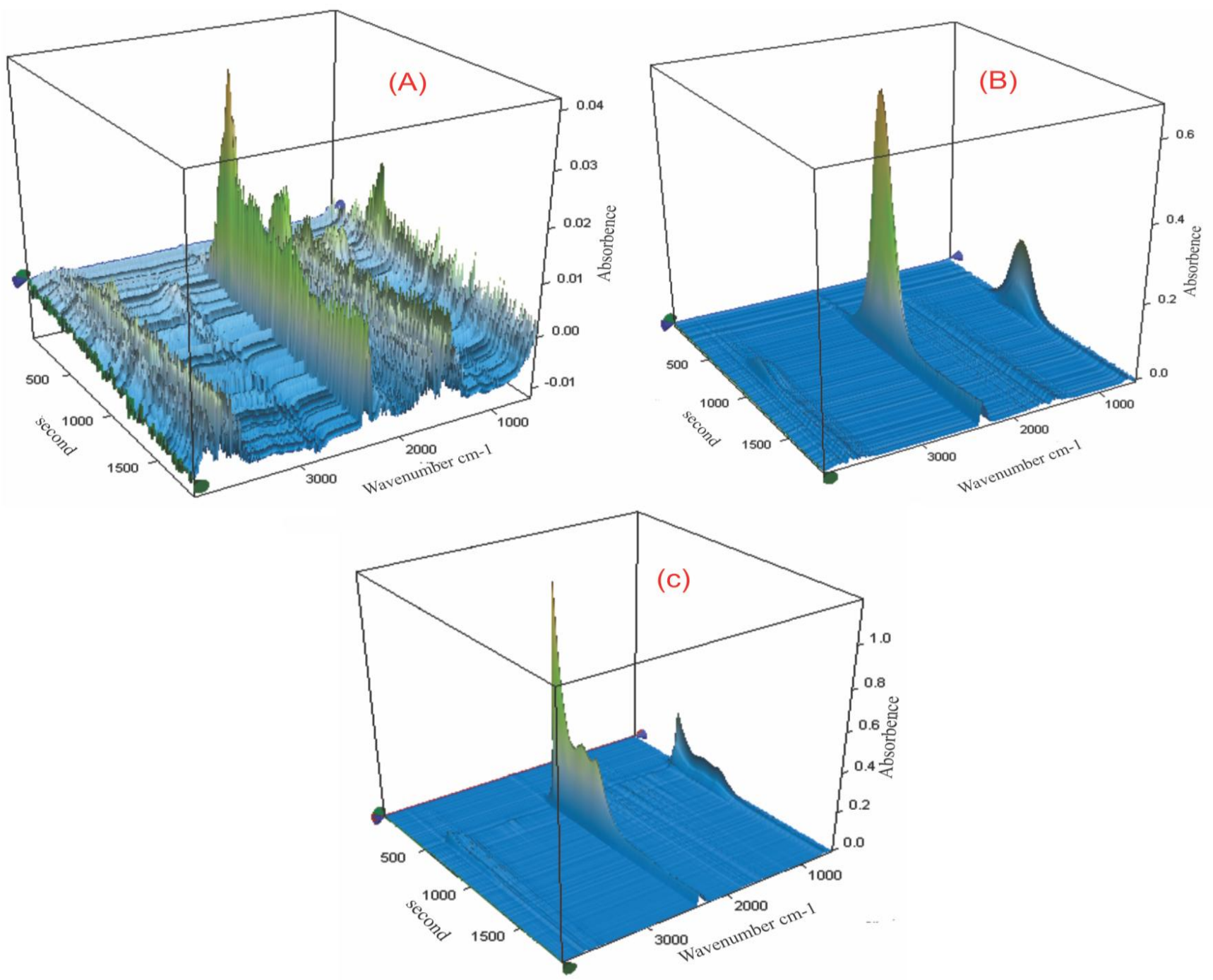

Figure3. 3D FTIR Spectra of Evolved Products During Thermal Degradation of Cow Dung; (A) Pyrolysis, (B) Combustion of $950^{\circ} \mathrm{C}$ Pyrolyzed Residue, (C) Combustion.

Based on the maximum point of the DTA curve, two representative temperatures $348^{\circ} \mathrm{C}$ and $500^{\circ} \mathrm{C}$ are chosen for two different pyrolysis stages, whereas temperatures of $312^{\circ} \mathrm{C}$ and $500^{\circ} \mathrm{C}$ are chosen for combustion stages, and $450^{\circ} \mathrm{C}$ is chosen as the representatives of the combustion of $950^{\circ} \mathrm{C}$ pyrolyzed cow-dung residue. The largest quantity and variety of gases are released out during the main devolatilization. The spectrum of evolved products at $348^{\circ} \mathrm{C}$ in the main devolatilization stage during pyrolysis is shown in supplementary File 1 . The characteristic bands of $\mathrm{CO}_{2}$ at $670 \mathrm{~cm}^{-1}, 2316-2356$ $\mathrm{cm}^{-1}$, and $\mathrm{CO}$ at $2180 \mathrm{~cm}^{-1}$ indicate their formation in this stage. The absorption bands at $2935 \mathrm{~cm}^{-1}$ show the presence of hydrocarbons, of which methane is the most abundant [22]. The bands between $1114 \mathrm{~cm}^{-1}$ and $1751 \mathrm{~cm}^{-1}$ indicate the release of some organics, including alcohols, aldehydes, acids, methanol, formaldehyde, acetic acid, and formic acid are generated in this stage. The nitrogen takes little proportion in ultimate analysis, so the absorbance bands of nitrogen containing product are very weak. The peaks appear in the range $3589-3860 \mathrm{~cm}^{-1}$ suffers interferences from water absorption, therefore it is concluded that the main gas products are $\mathrm{CO}_{2}, \mathrm{CO}$, methane, and some organics such as methanol, formaldehyde, acetic acid and formic acid.

The spectrum of evolved products at $500^{\circ} \mathrm{C}$ in the main carbonization stage during pyrolysis is shown in (Figure SF2), confirms the same characteristic bands, while there are some differences in the transmittance of some peaks e.g., carbonyl group peak $\left(1751 \mathrm{~cm}^{-1}\right.$ ) at $348^{\circ} \mathrm{C}$ (Figure SF1) almost 
disappeared in the spectrum of $500^{\circ} \mathrm{C}$ (Figure SF2). This is attributed to the complete removal of carbonyl group containing gases such as, formaldehyde, acetic acid and formic acid before entering in the main carbonization stage during pyrolysis, whereas the intensity of the peaks for water absorption almost double in the $500^{\circ} \mathrm{C}$ spectrum (Figure SF2) endorsed the fast removal of moisture. It can be noticed that the peak between $1114-1172 \mathrm{~cm}^{-1}$ at $348^{\circ} \mathrm{C}$ correspond to ether linkage (Fig. SF1) completely vanished in the $500^{\circ} \mathrm{C}$ spectrum (Figure $\mathrm{SF} 2$ ) attributed to the $\mathrm{C}-\mathrm{O}$ bonds fracture. The main identified components at this stage are $\mathrm{CO}_{2}, \mathrm{CO}, \mathrm{CH}_{4}$. The total infrared absorption becomes weaker with increasing temperature, indicating that the amount of volatiles evolving decreases.

The FTIR spectrum of evolved products during the combustion of $960^{\circ} \mathrm{C}$ pyrolyzed residue of cow-dung at $450^{\circ} \mathrm{C}$ is shown in (Figure SF3). As expected, spectrum shows only bend for $\mathrm{CO}_{2}$ confirmed major evolved gas. This suggests that cow-dung can be used as a save fuel for domestic uses, if subjected to undergo controlled pyrolysis prior to its complete combustion. The FTIR spectra of evolved products during combustion at $312^{\circ} \mathrm{C}$ and $500^{\circ} \mathrm{C}$ at a maximum degradation rate are shown respectively in (Figure SF4) and (Figure SF5). The presence of $\mathrm{CO}, \mathrm{CO}_{2}$ were confirmed by the appearance of representative bands during the combustion at $312^{\circ} \mathrm{C}$, while at $500^{\circ} \mathrm{C}$ the concentration of $\mathrm{CO}_{2}$ is large and show strong band in the similar region with no evidence for $\mathrm{CO}$. Taking account the above mention results it is possible to postulate that the main volatile products obtained are $\mathrm{CO}_{2}, \mathrm{CO}$, methanol, formaldehyde, formic acid, acetic acid (during pyrolysis) and $\mathrm{CO}_{2}, \mathrm{CO}$ (during combustion).

The volatile products produced by the thermal degradation of cow dung were determined by thermogravimetry coupled to a mass spectrometer. The single ion current curves for the evolved products during pyrolysis, combustion of $960^{\circ} \mathrm{C}$ pyrolyzed residue are shown in Figure 4. The release of carbon dioxide during the degradation stage was confirmed by a fragment at $\mathrm{m} / \mathrm{z} 44,43$ and 45 is also supported by FTIR data, where carbon dioxide has been observed. In all stages during thermal degradation of cowdung, the fragment at $\mathrm{m} / \mathrm{z} \mathrm{28}, 29$, confirmed the release of $\mathrm{CO}$ during combustion and pyrolysis and the presence of $\mathrm{H}_{2} \mathrm{~S}$ in both type of thermal degradation is supported by the fragments at $\mathrm{m} / \mathrm{z} 34$. The releasing of water begins at $80^{\circ} \mathrm{C}$ and show fragments at $\mathrm{m} / \mathrm{z} 18,17$ in the first and second degradation stage during pyrolysis and combustion of cow dung. The peaks at $\mathrm{m} / \mathrm{z} 27$ and 26 , which appear with strong intensity in the second degradation step, can be assigned to $\mathrm{HCN}$. The $\mathrm{m} / \mathrm{z} 30,12$ (HCHO) is produced from the degradation of cow-dung in the second degradation step. In addition, It is found that there is no toxic product evolved during the combustion of $960^{\circ} \mathrm{C}$ pyrolyzed residue.

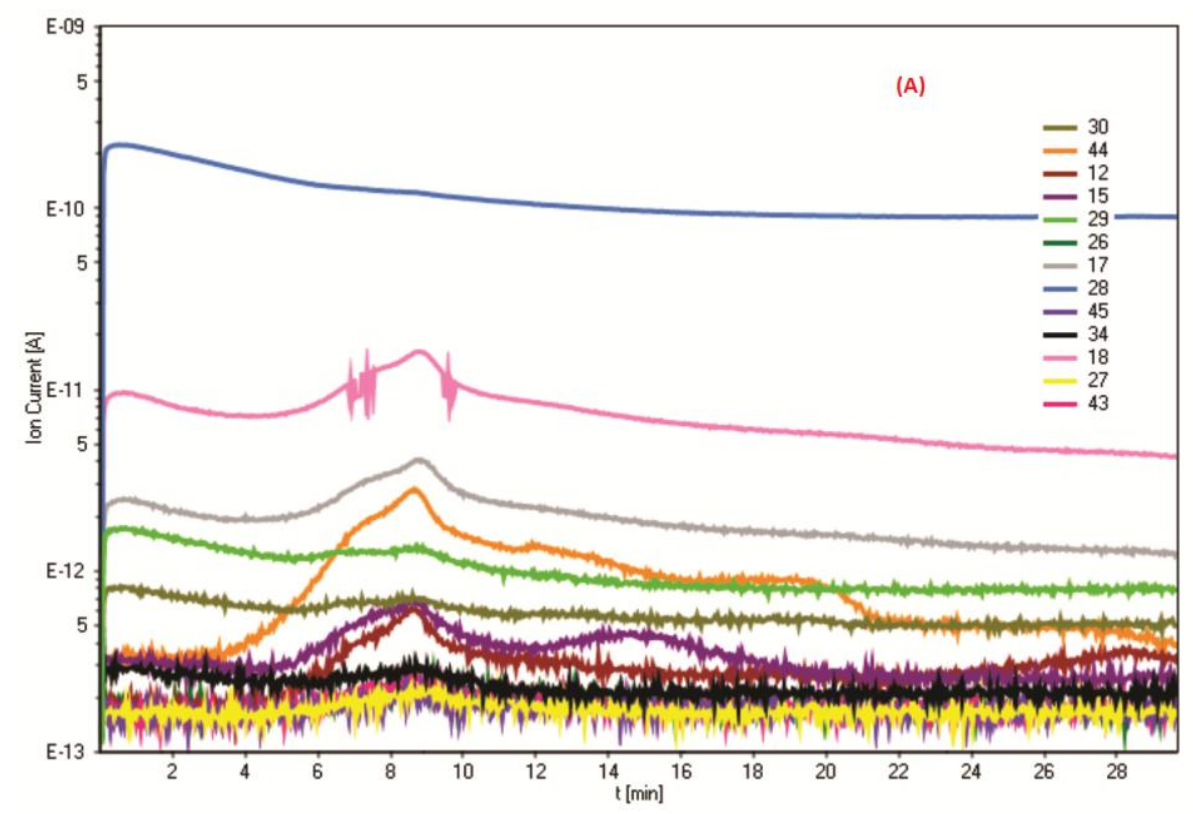



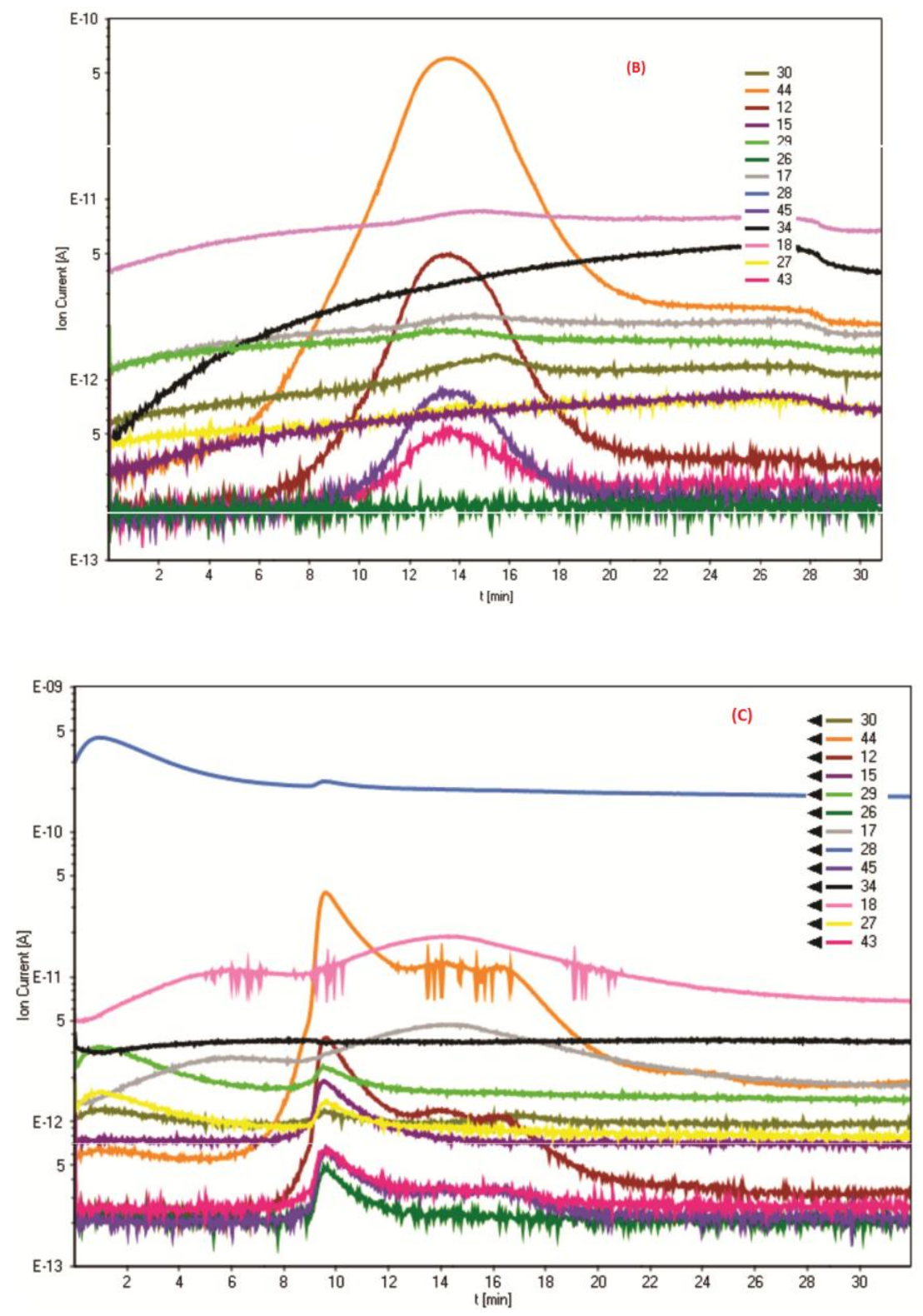

Figure4. Single Ion Current Curves for Evolved Products During Thermal Degradation of Cow Dung; (A) Pyrolysis, (B) Combustion of $950^{\circ} \mathrm{C}$ Pyrolyzed Residue, (C) Combustion.

The comparison between the results obtained with the TG-FTIR and the TG-MS shows some differences. For all profiles, fewer fluctuations appears on the curves of FTIR than on TG-MS ones. This is probably due to the optical cell of FTIR, which tends to average the signals because of its volume. In addition, a shift of curves appears between the two techniques. It can be explained by the different residence time induced by the experimental devices. In detail each gaseous compound $\mathrm{H}_{2} \mathrm{O}$ and $\mathrm{CO}_{2}$, the two profiles show same tendencies. Conversely, significant differences appear between the two analyses for $\mathrm{CO}$ and $\mathrm{CH}_{4}$. With mass spectrometry, $\mathrm{CO}$ is followed with the fragment at $\mathrm{m} / \mathrm{z} 28$ as mentioned previously; the emission begins from $200^{\circ} \mathrm{C}$ during combustion. Some gasses also appear on this temperature range and their ion fragmentation produces a fragment at $\mathrm{m} / \mathrm{z} 28$. The same observation can be performed for $\mathrm{CH}_{4}$. With FTIR, the release of $\mathrm{CH}_{4}$ occurs only after last step degradation. With TGMS, the fragment at $\mathrm{m} / \mathrm{z} 16$ shows an apparition of gases from $180^{\circ} \mathrm{C}$ due to the presence of water. Thus, the FTIR analysis and the mass spectrometry have advantages and disadvantages. However, using information provided by each of them, it is possible to have an identification of the gases emitted by degradation of cow dung during pyrolysis and combustion. 


\section{Conclusion}

The aim of this work was to study the spectroscopic and thermal degradation study of cow-dung during pyrolysis and combustion. The result of TG-FTIR-MS revealed that the main volatile product obtained were $\mathrm{CO}_{2}, \mathrm{CO}$, methanol, formaldehyde, formic acid, acetic acid (during pyrolysis) and $\mathrm{CO}_{2}, \mathrm{CO}$ (during combustion). Whereas the combustion of $960^{\circ} \mathrm{C}$ pyrolyzed residue of cow-dung at $500^{\circ} \mathrm{C}$ showed, only bend for $\mathrm{CO}_{2}$, as major evolved gas. This study guides us in the assessment of environmental healthpolicy strategies linked with exposure to biomass burning in this sub-tropical region, taking into account the exposure distribution in the population. Moreover, the use of alternative fuels to biomass fuel and use of improved ventilated stove is highly desired to be promoted by concerned organizations.

\section{REFERENCES}

[1] World Health Organization (2006) Fuels for Life: Household Energy and Health.

[2] The World Health Report (2002) Reducing Risks, Promoting health Life.

[3] Rehfuees, E. (2008) Air Quality and Health Fact Sheet 313.

[4] Barnes, D.F., Openshaw, K., Smith, K.R., van der Plas, R.1 (994) What makes people cook with improved biomass stoves? A Comparative International Review of Stove Programs. World Bank Technical Paper 242.

[5] Raiyani, C.V., Jani J.P., Desai, N.M., Shah, S.H., Shah, P.G., Kashyap, S.K. (1993) Assessment of indoor exposure to polycyclic aromatic hydrocarbons for urban poor using various types of cooking fuels. Bulletin of Environmental Contamination and Toxicology 50, 757-63.

[6] Venkataraman, C., Rao, G.U.M. (2001) Emission factors of carbon monoxide and size-resolved aerosols from biofuel combustion. Environmental Science \& Technology 35, 2100-2107.

[7] Chen, B.H., Hong, C.J., Pandey, M.R., Smith K.R. (1990) Indoor air pollution in developing countries. World Health Statistics 43,127-38.

[8] Behera, D., Jindal, S.K. (1991) Respiratory symptoms in Indian women using different cooking fuels. Chest 100, 385-8.

[9] Behera, D, Dash, S., Yadav, S, P. (1991) Carboxyhaemoglobin in women exposed to different cooking fuels. Thorax 46, 344-6.

[10] Torres-Duque, C., Maldonado, D., Perez-Padilla, R., Ezzati, M., Viegi, G. (2008) Forum of International Respiratory Studies (FIRS) Task Force on health effects of biomass exposure. Proceedings of the American Thoracic Society 5, 577-90.

[11] Fullerton, D.G., Bruce N., Gordon, S.B. (2008) Indoor air pollution from biomass fuel smoke is a major concern in the developing world. Transactions of the Royal Society of Tropical Medicine and Hygiene 102, 843-51.

[12] Lin, H.H., Murray M., Cohen, T., Colijn C., Ezzati, M. (2008) Effects of smoking and solid-fuel use on COPD, lung cancer, and TB in China, a time-based, multiple risk factors, modeling study. The Lancet 372, 1473-83

[13] Gong-Huan, Y., Nan-shan, Z. (2008) Effect on health from smoking and use of solid fuel in China. The Lancet 372, 1445-6.

[14] Lonnroth, K., Raviglione, M. (2008) Global epidemiology of TB, prospects for control. Seminars in Respiratory and Critical Care Medicine 29, 481-91.

[15] Bhatta, N., Dhakal, S.S., Rizal, S., Kralingen, K.W., Niessen, L. (2008) Clinical spectrum of patients presenting with bronchiectasis in Nepal, evidence of linkage between TB, tobacco smoking and toxic exposure to biomass smoke. Kathmandu University Medical Journal 6,195-203.

[16] Galeone, C., Pelucchi, C., La Vecchia, C., Negri, E., Bosetti, C., Ju, J. (2008) Indoor air pollution from solid fuel use, chronic lung diseases and lung cancer in Harbin Northeast China. European Journal of Cancer Prevention 17, 473-8. 
[17] Bhargava, A., Khanna, R.N, Bhargava, S.K., Kumar, S. (2004) Exposure risk to carcinogenic PAHs in indoor-air during biomass combustion whilst cooking in rural India. Atmospheric Environment 38, 4761-7.

[18] Pandey, A.K., Bajpayee, M., Parmar, D., Rastogi, S.K., Mathur, N., Seth, P.K., et al: (2005) DNA damage in lymphocytes of rural Indian women exposed to biomass fuel smoke as assessed by Comet assay. Environmental and Molecular Mutagenesis 45, 435-41.

[19] Johnson, J.M.F., Franzluebbers A.J., Weyers, S.L., Reicosky, D.C. (2007) Agricultural opportunities to mitigate greenhouse gas emissions. Environmental Pollution 150,107-24.

[20] Amon, B., Kryvoruchko, V., Amon, T., Zechmeister-Boltenstern S. (2006) Methane, nitrous oxide and ammonia emissions during storage and after application of dairy cattle slurry and influence of slurry treatment. Agriculture Ecosystems \& Environment 112, 153-62.

[21] Thomas, J.V. (1995) Coal, Anal. Chem. 67, 317R-319R.

[22] Liu, O., Wang, S., Zheng, Y., Luo, Z., Cen, K. (2008) Mechanism study of wood lignin pyrolysis by using TG-FTIR analysis, Journal of Analytical and Applied Pyrolysis 82, 70-177. 